\title{
Communicating the promise, risks, and ethics of large-scale, open space microbiome and metagenome research
}

\author{
Daria Shamarina' ${ }^{1}$ lana Stoyantcheva' ${ }^{1}$, Christopher E. Mason ${ }^{2,3,4^{*}}$, Kyle Bibby ${ }^{5}$ and Eran Elhaik ${ }^{6^{*}}$ (D)
}

\begin{abstract}
The public commonly associates microorganisms with pathogens. This suspicion of microorganisms is understandable, as historically microorganisms have killed more humans than any other agent while remaining largely unknown until the late seventeenth century with the works of van Leeuwenhoek and Kircher. Despite our improved understanding regarding microorganisms, the general public are apt to think of diseases rather than of the majority of harmless or beneficial species that inhabit our bodies and the built and natural environment. As long as microbiome research was confined to labs, the public's exposure to microbiology was limited. The recent launch of global microbiome surveys, such as the Earth Microbiome Project and MetaSUB (Metagenomics and Metadesign of Subways and Urban Biomes) project, has raised ethical, financial, feasibility, and sustainability concerns as to the public's level of understanding and potential reaction to the findings, which, done improperly, risk negative implications for ongoing and future investigations, but done correctly, can facilitate a new vision of "smart cities." To facilitate improved future research, we describe here the major concerns that our discussions with ethics committees, community leaders, and government officials have raised, and we expound on how to address them. We further discuss ethical considerations of microbiome surveys and provide practical recommendations for public engagement.
\end{abstract}

Keywords: Microbiome, Metagenome, Built environment, Public, MetaSUB, Concerns, Ethics

\section{Background}

Until recently, microbial communities have typically been studied in research facilities, largely out of the public eye. The rapid advent of high-throughput molecular techniques prompted a dramatic increase in the ability to study these communities in the human body [1] and over a wider range of habitats including urban $[2,3]$ and indoor [4-7] environments. These studies have provided valuable insight about the amount and type of bacteria in our environment and their ecology, source [8], and effects on our health [9] and behavior [10].

The vital contribution of microorganisms to our environment and health calls for large-scale efforts to chart

\footnotetext{
* Correspondence: chm2042@med.cornell.edu; e.elhaik@sheffield.ac.uk Daria Shamarina and lana Stoyantcheva are co-first authors.

Daria Shamarina and lana Stoyantcheva contributed equally to this work. ${ }^{2}$ Department of Physiology and Biophysics, Weill Cornell Medicine, New York, NY 10021, USA

${ }^{6}$ Department of Animal and Plant Sciences, University of Sheffield, Sheffield S10 2TN, UK

Full list of author information is available at the end of the article
}

our indoor and immediate outdoor microbiome environments. Consequently, over the past decade [11] several mapping efforts charting public restrooms [9], apartments [10], university classrooms and office buildings [11], hospitals [12], museum artifacts [13], dust [14], metropolitan subways [2,15-17] were launched. Reviews regarding the scientific findings of these studies investigating the "built environment" have recently been published [18]. One notable initiative, the MetaSUB project, originated to capture a city-scale molecular profile of DNA collected in New York [2]. The project has now grown into a consortium encompassing 72 major worldwide cities. Such studies challenge our perception of public health, safety, and privacy in urban environments, and seek to advance new strategies to protect our growing society, such as the design of "smart cities" that convey early warnings for potential epidemics and genetically protected infrastructure. While some studies aim to involve public members and educate them about their internal and external microbial environments, the 
growing number of community-level microbiome studies could inadvertently bring a negative image of microorganisms that would foster public fear [19] of such research and impede future microbiome investigations.

Building on our years of experience in the International MetaSUB Consortium [20-23], we compiled a list of concerns-all raised during our discussions with ethics committees, community leaders, and government officials-and address them. We also discuss how technological advances may change these assessments and provide recommendations for public engagement in future studies. The concerns identified and explained here, and the recommendations for public engagement, can be used as guidelines and benefit microbiome and metagenome research.

\section{The most common concerns associated with the public impact of microbiome research Ostracizing sensitive populations}

Since the earliest human microbiome project in 1683 when Antonie van Leeuwenhoek scraped "gritty matter" from between his teeth and visualized bacteria, research on human-associated microorganisms has focused on pathogens and the environments that allowed them to flourish [24], linking the presence of microorganisms and human contact with pathogenicity [25].

Microbiome studies are typically targeted, at least in part, at quantifying microbial biodiversity. Biodiversity of bacteria is measured in terms of taxonomy, diversity, evolutionary distance, their amount or frequency, and dynamics over time. Pathogenicity is related to, but not necessarily linked with biodiversity. Nonetheless, the presence of microorganisms, cleanliness, sanitation, and health quickly became embedded cross-culturally. These terms and themes have been used as a pejorative that stigmatized individuals, people, cultures, places, and cities [2628]. "Dirt," for instance, is a common pejorative in hygienic racism that has been applied to minorities, disadvantaged communities, and indigenous people who were then subjected to discrimination based on their hygiene and health [29]. For instance, due to poor housing conditions, Australian children living in remote indigenous communities experience high rates of increased transmission of infection compared to other Australian children. Racism and housing conditions are both associated with child health and with adult physical and mental health [29, 30]. That poverty, sanitation, and infection go hand in hand have thereby contributed to the stigmatization of sensitive populations. It follows that there is a well-placed concern that investigating the microbiome of a location may lead to its association with disease, to the detriment of its residents.

Recent studies, however, do not support the presumed association between biodiversity and pathogenicity. Microbiome studies can distinguish between ecologically varied diverse regions, which can be influenced by human biodiversity, and even reflected in the DNA left on ATM keypads [31], showing that the bacterial diversity is not generally related with pathogenicity or poverty. For example, in New York City, the Bronx was the most diverse borough both in terms of human and bacterial diversity [2]. Poverty rates in Manhattan are three quarters those of Brooklyn [32], but they have similar levels of bacterial diversity [2]. Governments are largely responsible for sanitation systems, particularly in large cities, and it is acknowledged that sanitary neglect is a population-wide hazard. Moreover, microorganisms are also produced by animals inhabiting the surrounding environment, like rats, dogs, and pigeons [2, 31] —and are thought to be among the major sources of zoonotic infections, such as T. gondii, in big cities [33]. The scientific community should thereby be cognizant of the language and its perception by the media and the general public. Interestingly, advances in epidemiology over the past two decades highlighted that "over-clean" environment pose a risk to human health, whereas exposure to little dirt (and most importantly, microorganisms) can be beneficial and even ward off disease [34, 35].

\section{Drawing the public away from transit systems}

Due to high levels of human traffic, handles, seats, and even the air transport systems are often perceived to be biologically contaminated [36-38]. Evidence suggests that during an epidemic outbreak, individuals may alter their behavior to reduce their risk of infection. For example, during the 2009 H1N1 influenza, 16-25\% of Americans avoided places where many people gathered, including public transportation [39]. Another example emerged during the 2014 Ebola outbreak [40] when the Centers for Disease Control and Prevention and World Health Organization recommended screening airport passengers arriving from countries with Ebola outbreaks [41, 42]. That outbreak caused significant financial damages, estimated in billions of dollars [43]. Concerns regarding potential public panic and financial and other damages to the city that may be caused by sampling transportation systems may, thereby, detract city officials from approving microbiome surveys.

However, public officials should be made aware that sampling the transport system can help monitor and fight the spread of pathogenic microorganisms, particularly during seasonal outbreaks, and develop strategies that the public can adopt to improve travelers' health, alleviate their concerns [44], and promote the use of public transport. Thus far, the majority of the bacteria identified in transit systems were benign commensal species typically found in our environment and skin [16]. In a survey of New York subway systems, Afshinnekoo et al. [2] found 1688 non-pathogenic 
bacteria species mostly associated with the skin flora. Only $31 \%$ of the species were identified as potentially opportunistic bacteria that, although possibly linked to diseases in people with compromised immune defense, are unlikely to be pathogenic in healthy individuals. The viruses found in the NY subway system were also generally harmless, as most belonged to the bacteriophages group that only infect bacteria [45]. We note, however, that $48 \%$ of the DNA belonged to unidentified organisms, which likely follow the proportion of other kingdoms of life that were identified: bacteria (46.9\%), eukaryotes $(0.8 \%)$, viruses $(0.03 \%)$, archaea $(0.003 \%)$, and plasmids $(0.001 \%)$ [2]. Finding antibiotic resistance species, not unexpectedly, is also unlikely. Only $8 \%$ of the hand-touch surfaces in busses, trains, stations, hotels, and public areas of a hospital in central London contained methicillin-sensitive Staphylococcus aureus and no sites grew methicillin-resistant S. aureus (MRSA) [46]. A slightly higher percentage (28\%) of bacteria cultured from the surfaces of NYC subways showed resistance to standard antibiotics [2]. In both studies, antibiotic resistance was defined by phenotypic assays. However, even when pathogenic organisms are found, the majority of infections can be avoided by washing hands with soap and water [47]. Notably, Afshinnekoo et al.'s [2] survey of the NY subway system was followed by a highest-ever peak in the number of users of the transit system $[48,49]$.

\section{Creating health risks to investigators}

Generally, the risk for infection during sampling is considered low, and no greater than typical everyday life. However, sampling specific sites, such as sewage systems, public toilets, or animals, may carry risk for investigators. For instance, sampling animals may put the investigator at risk for zoonotic disease transmission, and wastewater is known to contain viable human pathogens [50-52]. In addition to sampling animals and wastewater, taking samples from hospitals may result in exposure to antibiotic-resistant bacteria, such as MRSA or Pseudomonas aeruginosa [53], yet the risk of actual infection exists mostly for immunocompromised people and not necessarily the scientists taking samples [54]. Nonetheless, to minimize the risk of exposure, investigators should adopt standard safety procedures such as not being in close proximity to potentially contaminated surfaces and animals. When sampling hospitals or public transport systems, close contact with people should be avoided. Hand washing can also significantly reduce the risk of potential infections [47]. Wearing safety equipment, such as face masks and gloves, protects workers from potentially harmful microorganisms [55]. The proper equipment should be selected based on the estimated risk level of the studied site. For example, the National Institute for Health and safety has a document recommending different types of masks, based on the potential hazard and professional judgment [56].

\section{Disparaging cities and public sites}

Similar to as discussed above, the public's association between microbiology and disease may result in a negative association for microbiome sampling sites. It is not uncommon to find reports of toxins and small particles [57] alongside possible pathogenic microorganisms [58] living in solid surfaces or the air, which arguably, causes public anxiety. However, historical precedence can be misleading in this case. In modern cities, gaining information about microbial populations will enhance cities' efforts to improve public health [59]. We thereby suggest that microbiome studies will ultimately improve cities' reputation via the public's perception of greater public health monitoring.

Research efforts targeted at the indoor environment where most people spend $\sim 90 \%$ of their time have significant potential to improve public health. The linkages between dust, microorganisms, and diseases such as asthma and allergies are established but generally poorly understood [60, 61]. It has been shown that dust collected from air-conditioning filters had high level of potentially harmful gram-negative bacteria [62]. Airconditioners and ventilation systems may also contain bacteria, such as Mycobacterium tuberculosis, that can contribute to the bad quality of the air in apartments and buildings [62-64]. Hence, knowledge acquired about the pathogens in our immediate surrounding can also support efforts to improve the hygiene in public sites and reduce the risk of disease spread [65]. Ongoing public sampling and monitoring has an important role in alleviating existing fears of toxicity and pathogenicity.

\section{Stigmatizing healthcare facilities as healthcare hazards}

The problem of disease dissemination in healthcare facilities has existed since their establishment. Hospitals are the ideal environment for the spread of pathogenic bacteria, as both patients and health workers are in contact with contaminated surfaces, immune-compromised patients, and each other. One in 25 US hospital patients develops a nosocomial infection [66]; of those, one in 10 dies from their infection. Similarly, in Europe, 3.8\% of general ward and $15.3 \%$ intensive care unit patients acquired at least one nosocomial infection during their visit [67]. In some cases, patients are being advised to limit their hospital visits not only because the departments are busy [68] but because patients are at risk of contracting harmful infections [69-71]. These issues have already shaped the image of healthcare facilities as incubators that facilitate the creation and spread of antibiotic-resistant "superbugs" [72], and they are more acute in unhygienic institutions and those forced to 
release sick patients due to overcrowded departments, chiefly during seasonal outbreaks [73, 74]. Even sinks for hand washing have been recognized in aiding the spread of antibiotic-resistant bacterial pathogens [75]. It is now widely accepted that surfaces such as door handles, seats, and even floors are contaminated and may facilitate the rapid acquisition of antimicrobial resistance (AMR) [76] and transmission of several pathogens such as MRSA, VancomycinResistant Enterococci (VRE), and norovirus [77-80].

While microbiome hospital surveys may reinforce this image, they are a crucial step to find a solution to this problem. For example, public microbiome projects like the resistomap [81] have been valuable to understand the spread of AMR. Hospital sampling also allows understanding how antibiotic resistance spread over time and space, which allows healthcare practitioners to focus efforts on preventing contamination [82]. Therefore, the potential benefits in improving that treatment and the well-being of patients [83] outweigh the potential concerns regarding hospital swabbing. Such monitoring projects are currently underway $[17,84,85]$.

In addition to informing control of AMR and primary pathogens, microbiome surveys and monitoring efforts may inform the control of opportunistic pathogens. For example, Legionella grow in building plumbing systems and have emerged as a significant liability and public health concern for hospitals. Multiple strategies, such as on-site disinfection, are employed to control these opportunistic pathogens [86]. As these pathogens grow within a complex microbial ecology, microbiome monitoring has been proposed to inform their control [87].

\section{Encouraging fears of water safety}

The increasing international demand for bottled water underscores a declining trust in water safety; indeed, health concerns are listed as one of the chief drivers of this demand [88]. Microbiological contamination has long been a threat to water safety. This was first recognized by Dr. John Snow after the cholera outbreak in 1854 in central London, which took the lives of more than 500 people, and after which there was a new found awareness that cholera and other pathogens could be spread through the drinking water [89]. For these reasons, water facilities in the UK and many other countries are constantly monitored and tested for pathogens, toxins, or other forms of contamination to limit potential public health impact [90].

Such monitoring, however, generally excludes sewage conveyance and treatment systems that are known to contain human and animal pathogens [50-52]. Moreover, not all public water sources around the globe are being monitored regularly, or at all. Therefore, monitoring pathogen presence and viability in water facilities is essential to evaluate infectious risk and prioritize the water sources that require increased monitoring [90]. This is essential to provide more comprehensive protection of the public's safety and dynamic response to variegated risk across a city's sources of water. Efforts informed by microbiome surveys are already underway in various sites to improve pathogen detection methods for water monitoring $[91,92]$.

\section{Perpetuating privacy and confidentiality fears}

As privacy is becoming a growing concern, there is an increasing awareness of the risks of sharing information online. Paradoxically, though hacking to obtain biological information is extremely rare compared to other forms of hacking, the public is very conscious of privacy invasion associated with biological data [93]. While individual human identification from microbiome samples has yet to be achieved, some of the privacy concerns are valid. Fingertip microbial communities can show what keys of a computer keyboard were used and how recently, with traces being identifiable for up to 2 weeks at room temperature [94]. Lax and colleagues [85] showed that the microbiome of patients became more similar to their room microbiome the longer they stayed there. In other words, the room microbiome can be forensically analyzed to trace its inhabitants, but not only them. People have their own individual microbial "cloud" made up of biological particles emitted at a rate of $\sim 10^{6}$ per hour [95]. These airborne bacterial emissions contribute to the settled particles around people and can potentially be used to identify individuals or those who came in contact with the person [96]. It is therefore conceivable that sampling of crime scenes and suspects for their microbiome will become a forensic utility in the future.

While privacy risks are realistic, the field of microbial forensics today is still in its infancy, and the dynamic microbial nature poses great challenges that may question the usefulness of microbial-based tool for forensics. Franzosa et al. showed that individuals who supplied their microbiome from skin and stool samples as well as their genetic code could be identified with an $80 \%$ accuracy based on their stool sample; however, the accuracy dropped to $30 \%$ when microbiome from other sites of the body was sampled, such as skin and mouth [97]. This study and others indicate that it is potentially possible to match an individual with their microbiome; however, the microbiome data are likely to be used in conjunction with other data such as DNA profiles because microbiome composition could be influenced by several factors such as cosmetics, antibiotic use, and general state of health [98].

Another chief concern is that researchers will be able to infer information about the individual's health, habits, and lifestyle from their microbiome profile, which may then be accessed by third parties. This concern may also 
become realistic in the future when the microbiome can be harnessed to accurately trace the recent historical whereabouts of people [99]. Remarkably, microbiome privacy advocates have already released devices that can remove (enzymes) or replace (oligos) the DNA cloud that we leave behind [100].

To address all these concerns, privacy and safety measures should be applied to the collection and storage of microbiome data [101], and laws like the Genetic Information Nondiscrimination Act (GINA) of 2008 should be updated to include microbiome data. Such laws were created to protect personal information gathered from research involving collection of human data; however, in the case of GINA, non-human information is not protected. Since microbial DNA data are commonly stored in publicly available databases, there is a risk of identification even when the data are "anonymized" [102]. Misconceptions concerning anonymization and using meta-data resemble those made in the early genomic era, as human genomic data and their annotation were readily available online [103]. Previously, such a shift in data accessibility (dbGAP) has been put in place by the NIH and only after it became possible to extract information about individuals based on their genetic data [104]. Proper security measures should thereby be applied to microbiome data to prevent them from becoming a privacy risk.

\section{Raising new ethical questions}

The huge leap in microbiome research enabled by rapid sequencing technologies has resulted in the development of large databases where microbial samples from humans and the environment are stored. These collections raise many questions [105] concerning the ethical and social implications of sampling the human microbiome. The two most contested subjects are returning the results to participants and informed consent.

To address the first subject, we first have to formulate the ethics that govern the microbiome by deciding whether microorganisms are parts of our body or separate entities. Although they are clearly inter-connected and exist as dynamic, continually exchanging ecosystems, legally, they are often treated differently. If the microbiome is separate from tissues, humans may have fewer rights to their own microbiome than to their tissues that harbor it. There are several reasons why the decision is difficult. First, due to the infancy of human microbiome studies, much of the data remain uncharted, hard to interpret, and/or unmappable to known genomes. Second, encountering or searching for pathogenic agents raises questions as to whether the findings should be reported to patients or public health authorities [106], since the relationship between bacterial colonization and infection is not yet clear. Moreover, there is little clinical validation of microbiome results linking to health or disease [107]. It can therefore be argued that it is unethical to report any scientific findings back to participants, absent a clear indication and validation.

The second debatable subject deals with what informed consent should encompass, particularly in the absence of regulation on microbiome data. Currently, many countries including the UK and USA have laws that protect human subjects by requiring a full disclosure of any potential risk and benefits in participation [108]. In the UK, such laws fall under the remit of the NHS ethics review procedure (i.e., mainly research involving patients). However, as our understanding of the human microbiome grows, the laws involving data protection should be revised and the requirements from researchers should be clarified. For instance, the use of extensive 15-pages consent forms written in extensive verbiage, such as those used by the human microbiome project (HMP), has been criticized [109]. It has been proposed that a shorter version of the official consent documents should be produced to maximize the amount of crucial information the subject is expected to comprehend $[110,111]$.

\section{Demonizing microorganisms}

The idea that all bacteria are harmful and should be exterminated is substantially incorrect "common knowledge," yet various products are promoted in the popular media that "kill 99.9\% of all bacteria" [112]. Although we are surrounded by information sources urging us to get rid of bacteria as a source of morbidity and mortality, most bacteria are harmless and, often, beneficial [113]. Of the many bacteria that colonize our skin, nasal passages, and colon generally positively contribute to our well-being. The bacteria in our environment also influence our health and well-being [114-117]. Diverse colonies of bacteria live in symbiosis with our body and are essential for the healthy functioning of multiple bodily systems, like the GI tract. Disruption in the gut microflora may cause irritable bowel disease (IBD), characterized by a continuous inflammatory process in the gut, even after the primary pathogen has been eradicated [118]. Further investigations into how to stabilize and perhaps diversify our microenvironment may improve our quality of life [119].

Bacteria are also notoriously associated with dirt, diseases, and a general state of uncleanliness and struggling with the poor public relations of bacteria can be expected to hinder public microbiome initiatives at various levels. Nonetheless, similar to the complex interactions of commensal, opportunistic, and pathogenic bacteria of our internal microbiome, the bacteria of our external environment also have symbiotic relationships with each other and us [4]. Indoor microbial communities have been shown to significantly differ from the multiplicity 
of the outdoor microbiome described thus far [120]. The indoor communities are affected by the selective pressures of the environment, such as location, ventilation, and the presence of other humans. Students in a classroom increase the bacterial load of the air (by two orders of magnitude) when compared to an empty classroom [121]. Several studies have implied that a certain diversity and amount of bacteria in our indoor environment is beneficial and may prevent the development of illnesses like asthma in early stages of life [114-116]. These studies, though limited in size, offer a new angle to consider chronic illnesses and encourage a public's reconsideration of the value of bacteria and invite further research in this field.

\section{Recommendations}

Based on our long-term experience with public engagement $[22,122]$, we make several recommendations that can enhance the accessibility and transparency of microbiome research. Establishing a website that outlines the hypotheses, goals, and findings of the study would make a useful resource of information. Business cards with the website address, the purpose of the work, and its implications handed out to curious bystanders would mitigate anxiety and allow quick dissemination of the research data. Investigators should consider carefully how their activities and results can be misinterpreted [123] and avoid grades and labels. Keeping a live blog of the website designed for the broader audience would allow the team to announce upcoming steps and also share the experience of interacting with the public [124]. Such a platform will allow the researchers to promote the study on social media (Facebook and YouTube) as well as on various forums and encourage dialog between researchers, participants, and the general public [125].

We note that several guidelines for public engagement are already in place. For instance, the Responsible Research and Innovation (RRI) is an initiative by the European Union working toward an open science and innovation system that ultimately tackles societal changes [126]. It promotes the active engagement of key stakeholder groups (for example, members of the public, representatives of relevant interest groups, and leaders of relevant organizations), from the earliest stages of a project in order to ensure that the research is designed in close consultation with them and takes into account their questions and concerns. This could be a useful approach for researchers wishing to undertake microbiome studies to adopt existing guidelines set by these organizations.

Therefore, meeting with decision makers in the relevant organizations to secure their support of the project is a recommended step to keep the public representatives informed of ongoing research, as is now done with the City Council in NYC. This may also yield fruitful collaborations, as science can be linked with politics to increase the public outreach [127]. An example of public engagement could be delivering short tutorials for school children on the importance of washing hands and improving the overall hygiene in schools. Also, such engagement enables the teaching of emerging aspects of microbiome and metagenomics research, including epigenetics [128], extremophiles [129], and even studies of microbiomes in space [130]. Finally, it is important to communicate and evaluate the risks of identification from microbial samples and the accidental human DNA collected in the process to the public.

\section{Conclusions}

Genome-enabled technologies created a dramatic increase in our ability to study the microbiome in various environments and hosts including our, largely uncharted, indoor and outdoor environments. The insights gained from this research may substantially alter our prior perceptions on microorganisms and their effect on our lives and health. While the public has shown an interest in projects aiming to chart the gut microbiome of humans [131] or animals [132] and even test the microbiome behavior in space [7], there remain concerns that microbiome mapping of the open space environment would raise major public concerns, reservations from using public facilities, and social unrest. To make such research possible, it is imperative that scientists would understand these risks, develop research projects that mitigate them, and report the results in a responsible, transparent, and accurate manner.

\section{Abbreviations \\ AMR: Antimicrobial resistance; GINA: Genetic Information Nondiscrimination Act; MetaSUB: Metagenomics and Metadesign of Subways and Urban Biomes; MRSA: Methicillin-resistant Staphylococcus aureus; VRE: Vancomycin- Resistant Enterococci}

\section{Acknowledgements}

Not applicable.

\section{Funding}

We wish to thank the University of Sheffield's Research Ethics Committee (UREC) for helpful discussions. We would like to thank funding from the DNA Diagnostics Center, Bert L and N Kuggie Vallee Foundation, the WorldQuant Foundation, The Pershing Square Sohn Cancer Research Alliance, the National Institutes of Health (R25EB020393, R01ES021006), National Science Foundation $(1510925,1748019)$, the Bill and Melinda Gates Foundation (OPP1151054), and the Alfred P. Sloan Foundation (G-2015-13964).

\section{Availability of data and materials} Not applicable.

\section{Authors' contributions}

EE initiated the study following a discussion with CEM. DS and IS carried out all the research and wrote the manuscript. EE, $\mathrm{KB}$, and CEM revised the manuscript. All the authors approved the manuscript.

Ethics approval and consent to participate Not applicable. 


\section{Consent for publication}

Not applicable.

\section{Competing interests}

EE consults the DNA Diagnostics Center.

\section{Publisher's Note}

Springer Nature remains neutral with regard to jurisdictional claims in published maps and institutional affiliations.

\begin{abstract}
Author details
'Department of Molecular Biology and Biotechnology, University of Sheffield, Sheffield S10 2TN, UK. ${ }^{2}$ Department of Physiology and Biophysics, Weill Cornell Medicine, New York, NY 10021, USA. ${ }^{3}$ The HRH Prince Alwaleed Bin Talal Bin Abdulaziz Alsaud Institute for Computational Biomedicine, New York, NY 10021, USA. ${ }^{4}$ The Feil Family Brain and Mind Research Institute, Weill Cornell Medicine, New York, NY 10021, USA. ${ }^{5}$ University of Notre Dame Department of Civil and Environmental Engineering and Earth Sciences, University of Notre Dame, Notre Dame , IN 46556, USA. ${ }^{6}$ Department of Animal and Plant Sciences, University of Sheffield, Sheffield S10 2TN, UK.
\end{abstract}

Received: 31 May 2017 Accepted: 20 September 2017

Published online: 04 October 2017

\section{References}

1. Turnbaugh PJ, Ley RE, Hamady M, Fraser-Liggett CM, Knight R, Gordon JI. The human microbiome project. Nature. 2007;449:804-10.

2. Afshinnekoo E, Meydan C, Chowdhury S, Jaroudi D, Boyer C, Bernstein N, et al. Geospatial resolution of human and bacterial diversity with city-scale metagenomics. Cell Syst. 2015;1:72-87.

3. Hsu T, Joice R, Vallarino J, Abu-Ali G, Hartmann EM, Shafquat A, et al. Urban transit system microbial communities differ by surface type and interaction with humans and the environment. mSystems. 2016;1:18-6.

4. Kelley ST, Gilbert JA. Studying the microbiology of the indoor environment. Genome Biol. 2013;14:202.

5. Konya T, Scott JA. Recent advances in the microbiology of the built environment. Curr Sustain Energy Reports. 2014;1:35-42.

6. Adams Rl, Bateman AC, Bik HM, Meadow JF. Microbiota of the indoor environment: a meta-analysis. Microbiome. 2015;3:49.

7. Coil DA, Neches RY, Lang JM, Brown WE, Severance M, Cavalier DD, et al. Growth of 48 built environment bacterial isolates on board the International Space Station (ISS). PeerJ. 2016:4:1-11.

8. Stephens B. What have we learned about the microbiomes of indoor environments? mSystems. 2016;1:e00083-16.

9. Zheng P, Zeng B, Zhou C, Liu M, Fang Z, Xu X, et al. Gut microbiome remodeling induces depressive-like behaviors through a pathway mediated by the host's metabolism. Mol Psychiatry. 2016;21:786-96.

10. Vuong HE, Yano JM, Fung TC, Hsiao EY. The microbiome and host behavior. Annu Rev Neurosci. 2017;40:16-47.

11. Alfred P. Sloan Foundation. Microbiology of the built environment. https://sloan.org/programs/science/microbiology-of-the-built-environment. Accessed 26 Jul 2017.

12. Gibbons SM, Schwartz T, Fouquier J, Mitchell M, Sangwan N, Gilbert JA, et al. Ecological succession and viability of human-associated microbiota on restroom surfaces. Appl Environ Microbiol. 2015;81:765-73.

13. Flores GE, Bates ST, Caporaso JG, Lauber CL, Leff JW, Knight R, et al. Diversity, distribution and sources of bacteria in residential kitchens. Environ Microbiol. 2013;15:588-96.

14. Gilbert MTP. Documenting DNA in the dust. Mol Ecol. 2017:26:969-71.

15. Robertson CE, Baumgartner LK, Harris JK, Peterson KL, Stevens MJ, Frank DN, et al. Culture-independent analysis of aerosol microbiology in a metropolitan subway system. Appl Environ Microbiol. 2013;79:3485-93.

16. Leung MHY, Wilkins D, Li EKT, Kong FKF, Lee PKH. Indoor-air microbiome in an urban subway network: diversity and dynamics. Appl Environ Microbiol. 2014;80:6760-70

17. O'Hara NB, Reed HJ, Afshinnekoo E, Harvin D, Caplan N, Rosen G, Frye B, Woloszynek S, Ounit R, Levy S, Butler E, Mason CE. Metagenomic characterization of ambulances across the USA. Microbiome. 2017. 10.1186/ s40168-017-0339-6.
18. Adams RI, Bhangar S, Dannemiller KC, Eisen JA, Fierer N, Gilbert JA, et al Ten questions concerning the microbiomes of buildings. Build Environ. 2016;109:224-34.

19. Wassenaar M. Bacteria: more than pathogens. 2002. http://www.actionbioscience org/biodiversity/wassenaar.html. Accessed 30 May 2017.

20. Schmidt C. Living in a microbial world. Nat Biotechnol. 2017:35:401-3.

21. Mendes R, Garbeva P, Raaijmakers JM. The rhizosphere microbiome: significance of plant beneficial, plant pathogenic, and human pathogenic microorganisms. FEMS Microbiol Rev. 2013;37:634-63.

22. Mason CE, Garbarino J, Whitlock M, Sherlock G, Spellman P, Stoeckert C, et al. The power of engaging citizen scientists for scientific progress. J Microbiol Biol Educ. 2016;17:7-12.

23. Schmidt C. Living in a microbial world. Nat Biotech. 2017;35:401-3.

24. Leuwenhoek V. An extract of a letter from Mr. Anth. van Leuwenhoek, concerning animalcules found on the teeth; of the scaleyness of the skin,\&c. Philos Trans. 1693;17:646-9.

25. White P, Pullen A. Dispersing of dirt: inscribing bodies and polluting organisation. In: Dirty Work. London: Palgrave Macmillan UK; 2012. p. 143-64.

26. Bashford A, Hooker C. Sanitary failure and risk: pasteurisation, immunisation and the logics of prevention. In: Bashford A, Hooker C, editors. Contagion: Historical and cultural studies. London: Routledge; 2001. p. 129-52.

27. Metro News Reporter. Nine antibacterial-resistant superbugs found on the London Underground. 2017. http://metro.co.uk/2017/05/16/nine-of-worldsdeadliest-superbugs-have-been-found-on-london-underground-6640628/. Accessed 10 Aug 2017.

28. Osborne S. The map that shows Britain's "dirtiest" areas. 2016. http://www independent.co.uk/news/uk/home-news/the-map-that-shows-britainsdirtiest-areas-a6949191.html. Accessed 10 Aug 2017.

29. Priest N, Paradies $Y$, Stevens M, Bailie R. Exploring relationships between racism, housing and child illness in remote indigenous communities. J Epidemiol Community Heal. 2010;66:440-7.

30. Clucas DB, Carville KS, Connors C, Currie BJ, Carapetis JR, Andrews RM. Disease burden and health-care clinic attendances for young children in remote Aboriginal communities of northern Australia. Bull World Health Organ. 2008;86:275-81

31. Bik HM, Maritz JM, Luong A, Shin H, Dominguez-Bello MG, Carlton JM. Microbial community patterns associated with automated teller machine keypads in New York City. mSphere. 2016;1:226-16.

32. City-Data.com. Auburn, Washington (WA) poverty rate data-information about poor and low income residents living in this city. http://www.citydata.com/poverty/poverty-New-York-New-York.html. Accessed 17 May 2017.

33. Camossi LG, Fornazari F, Richini-Pereira VB, da Silva RC, Cardia DFF, Langoni H. Immunization of Wistar female rats with 255-Gy-irradiated Toxoplasma gondii: preventing parasite load and maternofoetal transmission. Exp Parasitol. 2014;145:157-63.

34. Fall T, Lundholm C, Örtqvist AK, Fall K, Fang F, Hedhammar $\AA$, et al. Early exposure to dogs and farm animals and the risk of childhood asthma. JAMA Pediatr. 2015;169:219.

35. Knight J. Puppy power. Nurs Stand. 2011;25:20-1.

36. Agg J. How clean are your hands? The answer may change how you wash. 2015 http://www.dailymail.co.uk/health/article-3269827/How-clean-hands-answerrevealed-unique-experiment-shock-change-wash.html. Accessed 29 May 2017.

37. World Health Organisation. Ambient air pollution: a global assessment of exposure and burden of disease. 2016. http://apps.who.int/iris/bitstream/ 10665/250141/1/9789241511353-eng.pdf?ua=1. Accessed 18 Aug 2017.

38. Pemberton B. Infographic reveals whether three, four or five-star hotels have the highest levels of bacteria in their bedrooms (and expensive doesn't always mean clean): Daily Mail; 2016. http://www.dailymail.co.uk/ travel/travel_news/article-3406623/Infographic-reveals-three-four-five-starhotels-highest-levels-bacteria-bedrooms-results-surprise-you.html. Accessed 29 May 2017.

39. Manfredi P. \& D'Onofrio A. Modeling the Interplay Between Human Behavior and the Spread of Infectious Diseases. Berlin: Springer-Verlag; 2013. p.329.

40. Jacobson $\mathrm{SH}, \mathrm{Yu} \mathrm{G}$, Jokela JA. A double-risk monitoring and movement restriction policy for Ebola entry screening at airports in the United States. Prev Med. 2016:88:33-8.

41. World Health Organisation. "WHO interim guidance for Ebola virus disease exit screening at airports, ports and land crossings." 2014.

42. Brown C. Airport exit and entry screening for Ebola: Centers for Disease Control and Prevention; 2014. https://www.cdc.gov/mmwr/preview/ mmwrhtml/mm6349a5.htm. Accessed 29 May 2017. 
43. World Bank. The economic impact of the 2014 Ebola epidemic: short- and medium-term estimates for West Africa. 2014.

44. SteelFisher GK, Blendon RJ, Kang M, Ward JR, Kahn EB, Maddox KE, et al. Adoption of preventive behaviors in response to the $2009 \mathrm{H} 1 \mathrm{~N} 1$ influenza pandemic: a multiethnic perspective. Influ Other Respir Viruses. 2015;9:131-42.

45. Sharma S, Chatterjee S, Datta S, Prasad R, Dubey D, Prasad RK, et al. Bacteriophages and its applications: an overview. Folia Microbiol. 2017;62:17-55.

46. Otter JA, French GL. Bacterial contamination on touch surfaces in the public transport system and in public areas of a hospital in London. Lett Appl Microbiol. 2009:49:803-5.

47. Mathur P. Hand hygiene: back to the basics of infection control. Indian J Med Res. 2011:134:611-20.

48. MTA. Highest Figures Since 1948. 2016. http://www.mta.info/news-ridershipsubway-new-york-city-transit/2016/04/18/highest-figures-1948. Accessed 17 May 2017.

49. Lai KM, Emberlin J, Colbeck I. Outdoor environments and human pathogens in air. Environ Health. 2009;8:593-600.

50. Cai L, Ju F, Zhang T. Tracking human sewage microbiome in a municipal wastewater treatment plant. Appl Microbiol Biotechnol. 2014;98:3317-26.

51. Bibby K, Viau E, Peccia J. Pyrosequencing of the $16 \mathrm{~S}$ rRNA gene to reveal bacterial pathogen diversity in biosolids. Water Res. 2010;44:4252-60.

52. Bibby K, Peccia J. Identification of viral pathogen diversity in sewage sludge by metagenome analysis. Environ Sci Technol. 2013;47:1945-51.

53. McClure JA, DeLongchamp JZ, Conly JM, Zhang K. A novel multiplex PCR assay for the detection of chlorhexidine/quaternary ammonium, mupirocin and methicillin resistance genes with simultaneous discrimination of Staphylococcus aureus from coagulase-negative staphylococci. J Clin Microbiol. 2017;55:1857-64.

54. Madigan MT, Clark DP, Stahl D, Martinko JM. Brock Biology of Microorganisms 13th edition. Benjamin Cummings; 2010

55. Chosewood LC, Wilson DE. Biosafety in microbiological and biomedical laboratories. Public Heal Serv. 1999;5:1-250.

56. U.S. Department of Health and Human Services. Personal protective equipment for infection control- masks and N95 respirators. https://www. fda.gov/MedicalDevices/ProductsandMedicalProcedures/ GeneralHospitalDevicesandSupplies/PersonalProtectiveEquipment/ ucm055977.htm. Accessed 29 July 2017.

57. Miesner EA, Rudnick SN, Hu F-C, Spengler JD, Preller L, Özkaynak H, et al. Particulate and nicotine sampling in public facilities and offices. JAPCA. 1989;39:1577-82.

58. Kuske CR, Barns SM, Grow CC, Merrill L, Dunbar J. Environmental survey for four pathogenic bacteria and closely related species using phylogenetic and functional genes. J Forensic Sci. 2006;51:548-58.

59. Shao M, Tang $X$, Zhang $Y$, Li W. City clusters in China: air and surface water pollution. Front Ecol Environ. 2006;4:353-61.

60. Mensah-Attipoe J, Täubel M, Hernandez M, Pitkäranta M, Reponen T. An emerging paradox: toward a better understanding of the potential benefits and adversity of microbe exposures in the indoor environment. Indoor Air. 2017;27:3-5.

61. Posa D, Hofmaier S, Arasi S, Matricardi PM. Natural evolution of Ige responses to mite allergens and relationship to progression of allergic disease: a review. Curr Allergy Asthma Rep. 2017;17:28.

62. Fox A, Rosario RM, Larsson L. Monitoring of bacterial sugars and hydroxy fatty acids in dust from air conditioners by gas chromatography-mass spectrometry. Appl Env Microbiol. 1993;59:4354-60.

63. Stanley NJ, Kuehn TH, Kim SW, Raynor PC, Anantharaman S, Ramakrishnan $\mathrm{MA}$, et al. Background culturable bacteria aerosol in two large public buildings using HVAC filters as long term, passive, high-volume air samplers. J Env Monit. 2008;10:474-81.

64. Murphy A, Allen J. Schools can be a hotbed of bacteria. 2006. http://abcnews, go.com/GMA/OnCall/story?id=2455073\&page=1. Accessed 17 May 2017.

65. Lee RL, Lee PH. To evaluate the effects of a simplified hand washing improvement program in schoolchildren with mild intellectual disability: a pilot study. Res Dev Disabil. 2014;35:3014-25.

66. Magill SS, Edwards JR, Bamberg W, Beldavs ZG, Dumyati G, Kainer MA, et al. Multistate point-prevalence survey of health care-associated infections. N Engl J Med. 2014;370:1198-208.

67. Guggenbichler JP, Assadian O, Boeswald M, Kramer A. Incidence and clinical implication of nosocomial infections associated with implantable biomaterials—catheters, ventilator-associated pneumonia, urinary tract infections. GMS Krankenhhyg Interdiszip. 2011;6:1.
68. itv news. Avoid A\&E unless necessary warn hospitals. 2015. http://www.itv com/news/wales/update/2015-01-06/avoid-a-e-unless-necessary-warnhospitals/. Accessed 15 May 2017.

69. Callahan A. New type of baby monitors offers "peace of mind" but may deliver just the opposite. 2017. https://www.washingtonpost.com/national/healthscience/new-type-of-baby-monitors-offers-peace-of-mind-but-may-deliver-justthe-opposite/2017/05/05/8d31a07e-09b7-1 1e7-93dc-00f9bdd74ed1_story. html?utm_term=.0a1f9eca6993. Accessed 15 May 2017.

70. Quach C, McArthur M, McGeer A, Li L, Simor A, Dionne M, et al. Risk of infection following a visit to the emergency department: a cohort study. CMAJ. 2012;184:232-9.

71. Lee $C-R$, Cho $H$, Jeong BC, Lee SH. Strategies to minimize antibiotic resistance. Int J Environ Res Public Health. 2013;10:4274-305.

72. Moritz A. Hospitals are a major health hazard: Natural news; 2008. http://www. naturalnews.com/023892_hospital_hospitals_health.html. Accessed 17 May 2017.

73. Hodgekiss A. Antibiotic resistance "could end modern medicine": UK's chief doctor issues stark warning as study reveals most of us don't even know what term really means. 2015. http://www.dailymail.co.uk/health/article3178432/Antibiotic-resistance-end-modern-medicine-UK-s-chief-doctorissues-stark-warning-study-reveals-don-t-know-term-really-means.html. Accessed 25 May 2017.

74. Borland S, Norton J. Shocking photos reveal the true scale of Britain's A\&E crisiswith mothers and children on floors and pensioners on trolleys being cared for by "corridor nurses." 2017. http.//www.dailymail.co.uk/news/article-4201548/none-hospital-picture-shambles-Casualty.html. Accessed 12 May 2017.

75. Lowe C, Willey B, O'Shaughnessy A, Lee W, Lum M, Pike K, et al. Outbreak of extended-spectrum $\beta$-lactamase-producing Klebsiella oxytoca infections associated with contaminated handwashing sinks. Emerg Infect Dis. 2012;18:1242-7.

76. Edelsberg J, Weycker D, Barron R, Li X, Wu H, Oster G, et al. Prevalence of antibiotic resistance in US hospitals. Diagn Microbiol Infect Dis. 2014;78:255-62.

77. Dancer SJ. Importance of the environment in methicillin-resistant Staphylococcus aureus acquisition: the case for hospital cleaning. Lancet Infect Dis. 2008;8:101-13.

78. Kaatz GW, Gitlin SD, Schaberg DR, Wilson KH, Kauffman CA, Seo SM, et al. Acquisition of Clostridium difficile from the hospital environment Am J Epidemiol. 1988;127:1289-94.

79. Martínez JA, Ruthazer R, Hansjosten K, Barefoot L, Snydman DR. Role of environmental contamination as a risk factor for acquisition of vancomycinresistant enterococci in patients treated in a medical intensive care unit. Arch Intern Med. 2003;163:1905.

80. Green J, Wright PA, Gallimore Cl, Mitchell O, Morgan-Capner P, Brown DW. The role of environmental contamination with small round structured viruses in a hospital outbreak investigated by reverse-transcriptase polymerase chain reaction assay. J Hosp Infect. 1998;39:39-45.

81. Yarygin KS, Kovarsky BA, Bibikova TS, Melnikov DS, Tyakht AV, Alexeev DG, ResistoMap-online visualization of human gut microbiota antibiotic resistome. Bioinformatics. 2017;33:2205-6.

82. Li Y, Lv Y, Xue F, Zheng B, Liu J, Zhang J. Antimicrobial resistance surveillance of doripenem in China. J Antibiot. 2015;68:496-500.

83. NERC. The UK's seven research councils unite to fight AMR. 2014 http://www.nerc.ac.uk/press/releases/2014/18-amr/. Accessed 15 May 2017.

84. Wilensky J. Collaborative startup will monitor pathogens in hospital settings. 2017. http://news.cornell.edu/stories/2017/05/collaborative-startup-willmonitor-pathogens-hospital-settings. Accessed 24 May 2017.

85. Lax S, Sangwan N, Smith D, Larsen P, Handley KM, Richardson M, et al. Bacterial colonization and succession in a newly opened hospital. Sci Transl Med. 2017:9:1-11.

86. Baron JL, Vikram A, Duda S, Stout JE, Bibby K. Shift in the microbial ecology of a hospital hot water system following the introduction of an on-site monochloramine disinfection system. PLoS One. 2014;9:69.

87. Wang $\mathrm{H}$, Edwards MA, Falkinham JO, Pruden A. Probiotic approach to pathogen control in premise plumbing systems? A review Environ Sci Technol. 2013:47:10117-28.

88. Doria MF. Bottled water versus tap water: understanding consumers' preferences. J Water Health. 2006;4:271-6.

89. Brody H, Rip MR, Vinten-Johansen P, Paneth N, Rachman S. Map-making and myth-making in Broad Street: the London cholera epidemic, 1854. Lancet. 2000;356:64-8.

90. Dufour A, Snozzi M, Koster W, Bartram J, Ronchi E, Fawtrell L, World Health Organization. Water, Sanitation and Health Team. Assessing Microbial Safety 
of Drinking Water: Improving Approaches and Methods. WHO Drinking Water Quality Series, OECD—WHO, Paris, France. London: IWA Publishing; 2003, p. 1-16

91. Stachler E, Kelty C, Sivaganesan M, Li X, Bibby K, Shanks OC. Quantitative CrAssphage pcr assays for human fecal pollution measurement. Environ Sci Technol. 2017;51 https://doi.org/10.1021/acs.est.7b02703.

92. Stachler E, Bibby K. Metagenomic evaluation of the highly abundant human gut bacteriophage crassphage for source tracking of human fecal pollution. Environ Sci Technol Lett. 2014;1:405-9.

93. Kaufman DJ, Murphy-Bollinger J, Scott J, Hudson KL. Public opinion about the importance of privacy in biobank research. Am J Hum Genet. 2009;85:643-54.

94. Fierer N, Lauber CL, Zhou N, McDonald D, Costello EK, Knight R. Forensic identification using skin bacterial communities. Proc Natl Acad Sci U S A. 2010;107:6477-81.

95. Qian J, Hospodsky D, Yamamoto N, Nazaroff WW, Peccia J. Size-resolved emission rates of airborne bacteria and fungi in an occupied classroom. Indoor Air. 2012;22:339-51.

96. Meadow JF, Altrichter AE, Bateman AC, Stenson J, Brown GZ, Green JL, et al. Humans differ in their personal microbial cloud. PeerJ. 2015;3:e1258.

97. Franzosa EA, Huang K, Meadow JF, Gevers D, Lemon KP, Bohannan BJM, et al. Identifying personal microbiomes using metagenomic codes. Proc Natl Acad Sci U S A. 2015;112:2930-8.

98. Findley K, Williams DR, Grice EA, Bonham VL. Health disparities and the microbiome. Trends Microbiol. 2016;24:847-50.

99. Hampton-Marcell JT, Lopez JV, Gilbert JA. The human microbiome: an emerging tool in forensics. Microb Biotechnol. 2017;10:228-30.

100. Biononymous.me. http://biononymous.me/. Accessed 24 May 2017.

101. Wagner J, Paulson JN, Wang X, Bhattacharjee B, Corrada BH. Privacy-preserving microbiome analysis using secure computation. Bioinformatics. 2016;32:1873-9.

102. NIH. Roadmap Epigenomics Project - Overview; 2013. p. 1-2. http://www.roadmapepigenomics.org/. Accessed 17 May 2017.

103. Gymrek M, McGuire AL, Golan D, Halperin E, Erlich Y. Identifying personal genomes by surname inference. Science. 2013;339:321-4.

104. NIH. Implementation guidance and instructions for applicants: policy for sharing of data obtained in $\mathrm{NIH}$-supported or conducted genome-wide association studies (GWAS); 2007. p. 1-4. https://grants.nih.gov/grants/ guide/notice-files/NOT-OD-08-013.html. Accessed 17 May 2017.

105. Di Bella JM, Bao Y, Gloor GB, Burton JP, Reid G. High throughput sequencing methods and analysis for microbiome research. J Microbiol Methods. 2013;95:401-14.

106. Beskow LM, Burke W, Merz JF, Barr PA, Terry S, Penchaszadeh VB, et al. Informed consent for population-based research involving genetics. JAMA. 2001;286:2315-21.

107. Bäckhed F, Fraser CM, Ringel Y, Sanders ME, Sartor RB, Sherman PM, et al. Defining a healthy human gut microbiome: current concepts, future directions, and clinical applications. Cell Host Microbe. 2012;12:611-22.

108. Department of Health. Research governance framework for health and social care. Health Soc Care Community. 2005;10:1-54.

109. Ormond KE, Cirino AL, Helenowski IB, Chisholm RL, Wolf WA. Assessing the understanding of biobank participants. Am J Med Genet Part A. 2009;149A:188-98.

110. Albala I, Doyle M, Appelbaum PS. The evolution of consent forms for research: a quarter century of changes. IRB Ethics Hum Res. 2010;32:7-11.

111. McGuire AL, Achenbaum LS, Whitney SN, Slashinski MJ, Versalovic J, Keitel WA, et al. Perspectives on human microbiome research ethics. J Empir Res Hum Res Ethics. 2012;7:1-14.

112. Bialik C. Kills 99.9\% of Germs-Under Some Lab Conditions. 2009. https://www.wsj.com/articles/SB126092257189692937. Accessed 18 Aug 2017.

113. Littman DR, Pamer EG. Role of the commensal microbiota in normal and pathogenic host immune responses. Cell Host and Microbe. 2011;10:311-23.

114. Ursell LK, Metcalf JL, Parfrey LW, Knight R. Defining the human microbiome. Nutr Rev. 2012;70:38-44.

115. Caporaso JG, Lauber CL, Costello EK, Berg-Lyons D, Gonzalez A, Stombaugh J et al. Moving pictures of the human microbiome. Genome Biol. 2011;12:50

116. Cho I, Blaser MJ. The human microbiome: at the interface of health and disease. Nat Rev Genet. 2012;13:260-70.

117. Gilbert JA, Neufeld JD, Raux-Deery E, Warren M, Smith A. Life in a world without microbes. PLoS Biol. 2014;12:e1002020.

118. Hanauer SB. Inflammatory bowel disease: epidemiology, pathogenesis, and therapeutic opportunities. Inflamm Bowel Dis. 2006;12:3-9.
119. Waldor MK, Tyson G, Borenstein E, Ochman H, Moeller A, Finlay BB, et al. Where next for microbiome research? PLoS Biol. 2015:13:e1002050.

120. Tringe SG, Zhang T, Liu X, Yu Y, Lee WH, Yap J, et al. The airbone metagenome in an indoor urban environment. PLoS One. 2008;3:e1862

121. Hospodsky D, Qian J, Nazaroff WW, Yamamoto N, Bibby K, Rismani-Yazdi H, et al. Human occupancy as a source of indoor airborne bacteria. PLoS One. 2012; $7:$ e34867.

122. Elhaik E, Greenspan E, Staats S, Krahn T, Tyler-Smith C, Xue Y, et al. The GenoChip: a new tool for genetic anthropology. Genome Biol Evol. 2013;5:1021-31

123. Yuhas A. Plague, anthrax and cheese? Scientists map bacteria on New York subway. 2015. https://www.theguardian.com/us-news/2015/feb/07/ scientists-map-bacteria-new-york-city-subways. Accessed 24 May 2017.

124. Wolinsky H. More than a blog. Eur Mol Biol Organ. 2011;12:1102-5.

125. Leshner Al. Public engagement with science. Science. 2003;299:977.

126. Horizon 2020. Responsible research \& innovation-European Commission. 2014. https://ec.europa.eu/programmes/horizon2020/en/h2020-section/ responsible-research-innovation. Accessed 29 May 2017.

127. Stilgoe J, Lock SJ, Wilsdon J. Why should we promote public engagement with science? Public Underst Sci. 2014:23:4-15.

128. Mason CE, Afshinnekoo E, Tighe S, Wu S, Levy S. International standards for genomes, transcriptomes, and metagenomes. J Biomol Tech. 2017:28:8-18.

129. Tighe S, Afshinnekoo E, Rock TM, McGrath K, Alexander N, Mclntyre A, et al. Genomic methods and microbiological technologies for profiling novel and extreme environments for the Extreme Microbiome Project (XMP). J Biomol Tech. 2017:28:31-9.

130. Mclntyre ABR, Rizzardi L, Yu AM, Alexander N, Rosen GL, Botkin DJ, et al. Nanopore sequencing in microgravity. NPJ Microgravity. 2016;2:16035.

131. National Institutes of Health. Human Microbiome Project. 2013

132. Wolfson R. Using big data and next-generation sequencing to improve your pet's health. 2017. http://www.huffingtonpost.com/entry/using-big-data-andnext-generation-sequencing-to-improve_us_595de0d1e4b085e766b51070?ncid= engmodushpmg00000004. Accessed 29 Jul 2017.

\section{Submit your next manuscript to BioMed Central and we will help you at every step:}

- We accept pre-submission inquiries

- Our selector tool helps you to find the most relevant journal

- We provide round the clock customer support

- Convenient online submission

- Thorough peer review

- Inclusion in PubMed and all major indexing services

- Maximum visibility for your research

Submit your manuscript at www.biomedcentral.com/submit
) Biomed Central 